\title{
Weed Management in Transplanted Rice through Pre Plant Application of Herbicides: A Review
}

\author{
G. Manisankar*, T. Ramesh and S. Rathika \\ Department of Agronomy, Anbil Dharmalingam Agricultural College and Research Institute, \\ Tamil Nadu Agricultural University, Trichy-620027, India \\ *Corresponding author
}

\section{Ke y w o r d s \\ Weed management, Transplanted rice, Preplant application, Glyphosate, glufosinate ammonium, Halosulfuron methyl}

\section{Article Info}

Accepted: 05 April 2020 Available Online: 10 May 2020

\section{A B S T R A C T}

Rice is an important food crop extensively grown in India. Several factors are responsible for reducing the rice productivity in worldwide. However, weed infestation is the major biotic threat to productivity of transplanted rice. Weeds are competed with rice by their high adaptability and faster growth, dominate the crop habitat and reduce the yield potential of rice. Weed management is an important agro-technique for successful transplanted rice cultivation. It can be achieved, either manual or mechanical or chemical weed control methods. Even though, hand weeding is an effective method of weed management, scarcity of labour and cost of weeding force the farmers to depend on chemical weed management. Herbicides offer the most effective, economical and practical way of weed management. Weed infestation before puddling may cause severe crop weed competition during early growth stage of rice by their re-emergence. Foliage active pre plant herbicides viz., glyphosate, glufosinate ammonium and halosulfuron methyl could be used effectively to control weeds before transplanting rice. As these herbicides would not have much soil activity, succeeding transplanted rice will not be affected. Controlling of emerged weeds leads exhaustion of weed seeds in the top soil and also the problematic weed like Cyperus would considerably reduce the weed population in the transplanted rice during early stages resulted in less crop weed competition and better growth and yield of rice. Few studies indicated that application of glyphosate $2.5 \mathrm{~kg} \mathrm{ha}^{-1}$ at 15 days before puddling found significantly reduced the weed density in transplanted rice. Similarly, glufosinate ammonium $1.0 \mathrm{~kg} \mathrm{ha}^{-1}$ as pre plant herbicide controlled the weeds effectively which resulted in lesser weed competition in transplanted rice. Thus, pre plant application (PPA) of glyphosate $2.5 \mathrm{~kg} \mathrm{ha}^{-1}$ or glufosinate ammonium $1.0 \mathrm{~kg} \mathrm{ha}^{-1}$ at 15 days before puddling recommended for effective weed control as well as higher productivity and profitability of transplanted rice.

\section{Introduction}

Rice (Oryza sativa L.) is the staple food for more than 60 per cent of the world population and its cultivation secures a livelihood for more than two billion people. In India, rice is grown in an area of 43.86 million hectare with a production of 104.80 million tonnes and an average productivity of $2.4 \mathrm{t} \mathrm{ha}^{-1}$ (Anonymous, 2016). In Tamil Nadu, rice is 
grown in an area of 1.85 million hectare with production of 6.95 million tonnes and productivity of $3.7 \mathrm{t} \mathrm{ha}^{-1}$ (Anonymous, 2019). Cauvery delta region of Tamil Nadu is known as "Rice bowl of South India".

Weeds are the major biotic constraint to reduce the rice productivity in worldwide. In transplanted rice, about $60 \%$ of the weeds emerge in the period between one week and one month after transplanting. These emerging weeds are competing with rice during effective tillering stage and decline the quantity of panicles leads to reduction in grain yield (Soe Thura, 2010). In transplanted rice, $45-51 \%$ yield reduction caused by weeds (Veeraputhiran and Balasubramanian, 2013).

In most of the rice growing areas, where one rice crop is being grown per year and rest of the period, the fields are left as fallow, weeds grown enormously during off season and poses serious threat in reducing the grain yield of rice. Rainfall during nursery period causes more weeds infestation and multiplication. Cyperus rotundus is one of the dominant weed, causes difficulty in land preparation for rice cultivation (Revathi et al., 2017). In addition, regeneration of Cyperus rhizomes and weeds infestation occur during early growth stages of rice due to improper land levelling as well as alternate wetting and drying irrigation pattern causes poor growth and yield of rice. Manual weeding of Cyperus rotundus islaborious and increases the cost of weeding. Hence, pre plant application of herbicide can be used for controlling the emerged weeds particularly Cyperus before transplanting which causes easy land preparation and less weeds in the rice field. Information on major weed flora in transplanted rice, different pre plant herbicides viz., glyphosate, glufosinate ammonium and halosulfuron methyl, their mode of action, weed control efficiency, favourable effect on crop growth and yield and economics were reviewed in this paper.

\section{Major weed flora in transplanted rice}

A broad spectrum of weed flora infests rice crop. Diversified weed flora being noticed in paddy fields of different states (Table 1).

\section{Relative density of weeds}

The dominant weed species associated with transplanted rice were sedges and shared the highest percentage of total weed density (73.3 $\%$ ) (Singh et al., 2005). Saha (2006) observed that predominant weed species consisted of $14.3 \%$ grasses, $46.2 \%$ sedges and $39.5 \%$ broad leaved weeds at 30 DAT in unweeded check. The major weed density observed were $16.5 \%$ grasses, $51.5 \%$ sedges and $32 \%$ broad leaved weeds in transplanted rice of Andhra (Kiran et al., 2010). Patra et al., (2011) noted that $27.2 \%$ grasses, $36.8 \%$ sedges and $36 \%$ broad leaved weeds in rice. Unweeded check registered more Cyperus rotundus in sodic soil environment of Tiruchirappalli (Revathi et al., 2017). In transplanted rice grasses $(65.4 \%)$ was the dominant weed, followed by sedges $(30.1 \%)$ and BLW (4.5\%) at 60 DAT in unweeded control (Manisankar, 2019b).

\section{Yield reduction by weeds}

Weeds caused maximum yield reduction in direct seeded rice of dry seeded soil than puddle soil (Moody, 1977). Ali and Sankaran (1984) reported unweeded control recorded $53 \%$ yield reduction in puddled condition and $91 \%$ in non-puddled conditions. Babu et al., (1992) stated that weeds present in the control plot compete with rice for light, nutrients and moisture and led to $80 \%$ declining of grain yield. In transplanted rice, about $60 \%$ of the weeds emerge in the period between one week to one month after transplanting, these emerged weeds are competing with rice 
during tillering stage and decline the quantity of panicles resulted in reduced grain yield. About 15-20 \% of the weed population emerged in the period between one month and two months after transplanting and 20-25\% of weeds emerged later (Zhang, 1996).

Uncontrolled growth of weeds during early stage (20-45 days after planting) led to reduction in yield was up to 25-53\% (Subbaiah and Sreedevi, 2000). Janiya (2002) stated that yield reduction by weeds was varied from 30-80 \% in direct seeded and 20$60 \%$ in transplanted rice. Similarly, weeds from unchecked plot caused 33-45 \% yield reduction observed by Manhas et al., (2012). Kumar et al., (2013) critically analysed the impact of weeds on yield reduction and found that reduction in rice yield was $15.3 \mathrm{~kg} \mathrm{ha}^{-1}$ for increase in one weed per meter square and $32.5 \mathrm{~kg} \mathrm{ha}^{-1}$ reduction in grain yield for each gram increase in weed biomass. Acharya and Bhattacharya (2013) observed that reduction in yield of rice by weeds in unweeded check was $32.97 \%$. Similarly, unweeded check in transplanted rice reduced $53.79 \%$ yield (Parthipan and Ravi, 2014). In sodic soil, weeds caused $32.4 \%$ yield reduction in transplanted rice (Manisankar, 2019b).

\section{Weed management through pre plant application of herbicides}

Application of herbicide before sowing or planting is called pre plant herbicides. It may be either foliar applied or incorporated in soil soon after its application. In case of photo volatile herbicide-fluchloralin, pre plant soil incorporation is practiced to control weeds in groundnut. Whereas, in case of rice ecosystem, pre-plant foliar spraying of glyphosate is recommended to control weeds particularly perennial weeds like Cyperus rotundus. Foliage active pre plant herbicides viz., glyphosate, glufosinate ammonium and halosulfuron methyl could be used effectively to control weeds before transplanting rice. As these herbicides would not have much soil activity, succeeding transplanted rice will not be affected. Controlling of emerged weeds leads exhaustion of weed seeds in the top soil and also the problematic weed like Cyperus would considerably reduce the weed population in the transplanted rice during early stages resulted in less crop weed competition and better growth and yield of rice.

\section{Pre plant application of herbicides}

\section{Glyphosate (N-(phosphonomethyl) glycine)}

Glyphosate is a non-selective, broad spectrum herbicide that is active on many species of green plants through foliar translocation. It is used to control emerged weeds in non-crop situation. It was first introduced in 1974 for post emergence weed control following discovery of its herbicidal properties by John Franz in 1970 (Anonymous, 2005). Glyphosate can be sprayed as pre plant application for weed control in transplanted rice (Parthipan et al., 2016).

\section{Mode of action}

Glyphosate inhibits 5-enolpyruvyl shikimate3-phosphate (EPSP) which led to reducing aromatic amino acids that required for protein synthesis or biosynthetic pathways like tryptophan, tyrosine and phenylalanine resulted in growth failure of plants. It absorbed through foliage and translocated through symplast pathway and accumulates in all the plant parts. Residuality of glyphosate was none ( $<1$ month). It is non selective in nature and widely used low cost herbicide (Mueller et al., 2005). It was readily translocated, causing chlorosis, necrosis and finally kill the plant cells (Deeds et al., 2006). Four to seven days after treatment, phytotoxicity occurred in plants (Senseman and scott, 2007). 


\section{Weed control efficiency (WCE)}

The lowest weed density, dry weight and WCE observed under pre sowing spraying of glyphosate $1.5 \mathrm{~kg} \mathrm{ha}^{-1}$ in drum seeded wet rice (Subramanian et al., 2004). Prakash et al., (2013) revealed that glyphosate $0.75 \mathrm{~kg}$ $\mathrm{ha}^{-1}$ at 15 days before sowing was effective in controlling of weeds and higher WCE. Similarly, pre plant application (PPA) of glyphosate $2.5 \mathrm{~kg} \mathrm{ha}^{-1}$ registered significantly lower weed density $\left(18.1\right.$ and $\left.16.7 \mathrm{~m}^{-2}\right)$, dry weight (14.5 and $\left.15.0 \mathrm{~g} \mathrm{~m}^{-2}\right)$ and higher weed control efficiency (78.1 and $88.3 \%$ ) on 40 and 60 DAT respectively (Manisankar et al., 2019).

\section{Effect on rice}

Higher grain yield was obtained under pre plant application of glyphosate at 15 days before transplanting (Veeraputhiran and Balasubramanian, 2010). Similarly, Prakash et al., (2013) stated that glyphosate $0.75 \mathrm{~kg}$ $\mathrm{ha}^{-1}$ at 15 days before sowing found increased yield of rice. Pre plant application of glyphosate at 15 days before transplanting of rice recorded higher grain yield (Parthipan et al., 2013). Ramachandra et al., (2014) found that pre plant application of glyphosate 0.75 $\mathrm{kg} \mathrm{ha} \mathrm{ha}^{-1}$ at 15 days before transplanting improved the yield of rice $\left(7.02 \mathrm{t} . \mathrm{ha}^{-1}\right)$. In sodic soil, Manisankar et al., (2019) revealed that application of glyphosate $2.5 \mathrm{~kg} \mathrm{ha}^{-1}$ as a pre plant herbicide registered significantly higher growth parameters like plant height, tillers and dry matter production and yield attributes and grain yield $\left(4232 \mathrm{~kg} \mathrm{ha}^{-1}\right)$ than control.

\section{Soil micro flora}

Glyphosate was found to be a best herbicide to maintain soil micro flora in sorghum rhizosphere as compared to anilophos, pretilachlor and 2, 4-D (Sreeramalu and
Prabhakar shetty, 1996). After the application of glyphosate with an incubation period of 32 days, the bacterial population decreased but actinomycetes and fungal population increased (Araújo et al., 2003).

\section{Economics}

Glyphosate application at $0.75 \mathrm{~kg} \mathrm{ha}^{-1}$ on 15 days before transplanting of rice in combination with pre emergence application of bensulfuron methyl + pretilachlor at 5 DAT gave maximum profit in rice (Ramachandra $e t$ al., 2014). Similarly, Manisankar et al., (2019) found that pre plant application of glyphosate $2.5 \mathrm{~kg} \mathrm{ha}^{-1}$ registered higher net return and $\mathrm{B}: \mathrm{C}$ ratio of transplanted rice than control.

\section{Glufosinate ammonium (2-amino-4- (hydroxymethylphoshinyl) butanoic acid)}

Glufosinate ammonium is a contact herbicide, damage is restricted to those parts of the plant that have been in contact with the spray (Pline et al., 1999). It used to control annual and perennial grasses, sedges and BLW in noncropped situation (Coetzer and Al-Khatib, 2001). According to Everman et al., (2009), glufosinate ammonium is readily degraded by microorganisms. It has no residual activity. It has a phosphorus containing amino acid and also known as phosphinothricin is a nonvolatile salt, soluble in polar solvents and water and insoluble in non-polar organic solvents. It is a non-selective post emergence contact herbicide (Li et al., 2014). Information on the use of this herbicide as pre plant application in transplanted rice is very limited.

\section{Mode of action}

Glufosinate inhibited the activity of glutamine synthase, which is essential for conversion of glutamate plus ammonium to glutamine led to 
accumulation of ammonia in the plant, resulted in destroying cells directly and inhibits photosystem I and II. Herbicide absorbed mostly through foliage of the plant, small quantity of glufosinate may absorbed through roots and limited translocation via xylem and phloem. The chlorosis symptom is visible at 3 to 5 day after transplanting followed by necrosis and death (Senseman and scott, 2007).

\section{Effect on rice}

An attempt was made by Manisankar et al., (2019) on the use of glufosinate ammonium as pre plant herbicide in transplanted paddy revealed that application of glufosinate ammonium $1.0 \mathrm{~kg} \mathrm{ha}{ }^{-1} 15$ days before puddling controlled all weeds and particularly Cyperus before puddling and recorded lesser weed density, dry weight and higher weed control efficiency in transplanted rice than control. Significantly taller plants, tiller population, dry matter production, more number of productive tillers, filled grains and higher grain yield were recorded with application of glufosinate ammonium over control. In addition, it also gave higher net return and B:C ratio over control. However, the effect of glufosinate ammonium was on par with glyphosate (Manisankar et al., 2019). Hence, glufosinate ammonium $1.0 \mathrm{~kg} \mathrm{ha}^{-1}$ could be used as alternative herbicide in future considering the negative issues of glyphosate (Manisankar, 2019b).

\section{Soil micro flora}

After spray of glufosinate ammonium only fungal species were observed namely Acremonium species, Gongronellabutleri, paecilomycesmarguandi and sporothrix species. Additionally, it contains lucinostatine antimicrobial property (Fukushima et al., 1983).
Halosulfuron methyl (Methyl 5 - [((4, 6dimethoxy - 2 pyrimidinyl) amino) carbonyl aminosulfonyl]-3-chloro-1- methy l-1 H-pyrazole - 4 - carboxylate)

Halosulfuron methyl is a selective post emergence herbicide used to control sedge and other weeds. It is belonging to sulfonyl urea group of herbicides. It completely controls the Cyperus and reduces tuber viability. Halosulfuron controlled purple nutsedge and similar weeds that are difficult to manage (Suganthi, 2013).

\section{Mode of action}

Halosulfuron methyl comes under sulfonyl urea group of herbicide, used for control the emerged sedges. It affects acetolactate synthase (ALS) enzyme, caused rapid reduction of cell division and plant growth. Growth and development of treated plant inhibit within few hours and susceptible weeds are no longer competitive with the crop. Inhibition of growth followed by chlorotic and necrotic in meristematic areas with complete control typically occurring within 1-2 weeks. The residuality is intermediate (1-4 months) (Suganthi, 2013).

\section{Weed control efficiency}

Halosulfuron methyl is effectively used to control Cyperus rotundus in many other crops. It effectively controlled Cyperus rotundus in sugarcane at $3.3 \mathrm{~g}^{-1} 10$ lit (Rathika et al., 2013). Similarly, application of halosulfuron methyl $75 \%$ WG at $3.3 \mathrm{~g}^{-1} 10$ lit foliar spray at 4 to 6 leaf stage of Cyperus rotundus was found effective to reduce the competition and re-emergence (Maitri et al., 2017). Kumar (2018) reported that foliar application of halosulfuron methyl $75 \% \mathrm{WG}$ $67.5 \mathrm{~g} \mathrm{ha}^{-1}$ on 18 DAS at 3-4 leaf stage of Cyperus found significantly effective. In rice, when used as pre plant herbicide to control 
weeds, it was ineffective in controlling grownup or matured weeds including Cyperus resulted in poor weed control efficiency and grain yield of rice. When compared to glyphosate and glufosinate, use of halosulfuron methyl $67.5 \mathrm{gha}^{-1}$ as PPA recorded lesser weed control, grain yield and economics of transplanted rice (Manisankar, 2019b).

Table.1 Weed species found in paddy fields of different states

\begin{tabular}{|c|c|c|}
\hline State & Weed species & Author \\
\hline Tamil Nadu & $\begin{array}{l}\text { Echinochloa colona, Leptochloa chinensis, Cyperus } \\
\text { rotundus, Cyperus difformis, Eclipta alba, Marselia } \\
\text { quadrifoliata and Sphenoclea zeylonica. }\end{array}$ & $\begin{array}{l}\text { Kathirvelan and } \\
\text { Vaiyapuri (2003) }\end{array}$ \\
\hline Odisha & $\begin{array}{l}\text { Echinochloa species, Cyperus iria, Fimbristylis } \\
\text { miliacea, Sphenochlea zeylanica, Ludwigia parviflora } \\
\text { and Aeschynomene indica. }\end{array}$ & Saha (2006) \\
\hline Haryana & $\begin{array}{l}\text { Echinocloa glabrescens, Echinochloa colona, Cyperus } \\
\text { rotundus, Cyperus iria, Cyperus difformis, Fimbristyli } \\
\text { smiliaceae, Ammania baccifera and Euphorbia species. }\end{array}$ & Yadav et al., (2009) \\
\hline $\begin{array}{l}\text { Himachal } \\
\text { Pradesh }\end{array}$ & $\begin{array}{l}\text { Echinochloa colona, Cyperus iria and Ammania } \\
\text { baccifera. }\end{array}$ & Kumar et al., (2013) \\
\hline $\begin{array}{l}\text { Andhra } \\
\text { Pradesh }\end{array}$ & $\begin{array}{l}\text { Bacopa monnieri, Ammania baccifera Chromolaena } \\
\text { odorata, Merremia gangetica and Marsilea quadrifolia }\end{array}$ & Nagaraju et al., (2014) \\
\hline Uttarakhand & $\begin{array}{l}\text { Echinochloa species, Leptochloa chinensis, Commelina } \\
\text { benghalensis, Caesulia axillaris and Cyperus species }\end{array}$ & $\begin{array}{l}\text { Bhimwal and Pandey } \\
\text { (2015) }\end{array}$ \\
\hline Punjab. & $\begin{array}{l}\text { Echinochloa species, Cyperus species, Ischaemum } \\
\text { rugosum, Digitaria sanguinalis, Caesulia axillaris and } \\
\text { Fimbristylistenera }\end{array}$ & Saini and Chopra (2015) \\
\hline Tamil Nadu & $\begin{array}{l}\text { Cynodondactylon, Echinochloa colona, Panicum } \\
\text { repens, Cyperus rotundus, Cyperus difformis, } \\
\text { Ammannia baccifera, Ipomoea aquatica and Marsilea } \\
\text { quadrifolia }\end{array}$ & $\begin{array}{l}\text { Nivetha et al., (2017), } \\
\text { Revathi et al., (2017) and } \\
\text { Manisankar et al., (2019) }\end{array}$ \\
\hline
\end{tabular}

\section{Herbicide residue in soil}

Halosulfuron is relatively immobile in soil and degrades rapidly, therefore has low leaching potential and therefore do not contaminate groundwater and the environment (Senseman and scott, 2007). Soil, sugarcane juice and leaves samples collected at harvest showed the residues of halosulfuron below detectable level (BDL) of
$0.03 \mathrm{mg} \mathrm{kg}^{-1}$ at both recommended dose $(67.5$ $\mathrm{g} \mathrm{ha}^{-1}$ ) and double dose (135 $\mathrm{g} \mathrm{ha}^{-1}$ ) (Anil et al., 2016).

Hence concluded, from the above review, controlling of emerged weeds before puddling using pre plant application of herbicides leads exhaustion of weed seeds in the top soil and also problematic weed like Cyperus would considerably reduce the weed population in 
the transplanted rice during early stages resulted in less crop weed competition and better growth and yield of rice. Many studies concluded that pre plant application of glyphosate $2.5 \mathrm{~kg} \mathrm{ha}^{-1}$ at 15 days before puddling recommended for effective weed control as well as higher productivity and profitability of transplanted rice. However, recent reports on glyphosate toxicity on human beings and banning of glyphosate by some states like Kerala, Punjab, Maharashtra and Andhra Pradesh forced the scientist to find out an alternative herbicide for this. Hence, glufosinate ammonium $1.0 \mathrm{~kg} \mathrm{ha}{ }^{-1}$ could be used as alternative herbicide in future considering the negative issues of glyphosate.

\section{References}

Acharya, S. S., and Bhattacharya, S. P. 2013. Comparative Efficacy of Pyrazosulfuron Ethyl and Bentazon with Acetamides for Weed Control in Transplanted Boro Rice (Oryza sativa L.) in the Lower Gangetic Plain Zone of West Bengal, India. International Journal of Bio-Resource \& Stress Management. 4 (4): 506-509.

Ali, A. M., and Sankaran, S. 1984. Crop-weed competition in direct seeded, flooded and rainfed bunded rice. International Rice Research Newsletter. 9 (2): 22.

Anil, D., S. S. Sushil, S. S. Punia and Samar Singh. 2016. Determination of harvest time residues of halosulfuron in sugarcane and soil. Agriculture Research Journal. 53(2): 280-282.

Anonymous, 2005. Monsanto Company. Annual Report.

https://monsanto.com/app/uploads/2017/0 5/2015_Annual_Report_FullWeb.pdf.

Anonymous, 2016. Area and production of cereals. National Food Security Mission.https://www.nfsm.gov.in/StatusP aper/Rice2016.pdf.

Anonymous, 2019. Area and production of cereals, Department of Economics and Statistics. https://eands.dacnet.nic.in/.

Araujo, A. D., R. T. R. Monteiro and Abarkeli, R.
B. 2003. Effect of glyphosate on the microbial activity of two Brazilian soils. Chemosphere. 52 (5): 799-804.

Babu, D. P. S., B. T. S. Moorthy, S. Rajamani and Manna, G. B. 1992. Integrated weed management benefits from direct seeded upland rice. Indian Journal of Agronomy. 42 (1): 7-8.

Bhimwal, J. P., and Pandey, P. C. 2015. BioEfficacy of flucetosulfuron for broad spectrum weed control in transplanted rice (Oryza sativa L.). Annals of Agricultural Research. 36 (1): 82-85.

Coetzer, E., and Al-Khatib, K. 2001. Photosynthetic inhibition and ammonium accumulation in Palmer amaranth after glufosinate application. Weed Science. 49 (4): 454-459.

Deeds, Z. A., K. Al-Khatib, D. E. Peterson and Stahlman, P. W. 2006. Wheat response to simulated drift of glyphosate and imazamox applied at two growth stages. Weed Technology. 20 (1): 23-31.

Everman, J. W., C. R. Mayhew, J. D. Burton, A. C. York and John W. W. 2009. Absorption, translocation, and metabolism of 14 C-glufosinate in glufosinate-resistant corn, goosegrass (Eleusine indica), large crabgrass (Digitaria sanguinalis) and sicklepod (Senna obtusifolia). Weed Science. 57 (1): 1-5.

Fukushima, K., T. Arai, Y. Mori, M. Tsuboi and Suzuki, M. 1983. Studies on peptide antibiotics, leucinostatins. II. The structures of leucinostatins $\mathrm{A}$ and $\mathrm{B}$. The Journal of antibiotics. 36 (12): 16131630.

Janiya, J. D., 2002. Weed management in major crops in the Philippines: Los Banos, Laguna, Philippines. Weed Science Society of the Philippines. pp.17-37.

Kathirvelan, P., and Vaiyapuri, V. 2003. Relative efficacy of herbicides in transplanted rice. Indian Journal of Weed Science. 35 (3\&4): 257-258.

Kiran, Y. D., D. Subramanyam and Sumathi, V. 2010. Growth and yield of transplanted rice (Oryza sativa) as influenced by sequential application of herbicides. Indian Journal of Weed Science. 42 (3): 
226-228.

Kumar, M., 2018. Halosulfuron Methyl 75\% WG (Sempra) - A New Herbicide for the Control of Cyperus rotundus in Maize (Zea mays L.) Crop in Bihar. International Journal of Current Microbiology and Applied Sciences. 7 (3): 2319-7706.

Kumar, S., S. S. Rana and Chander, N. 2013. Mixed weed flora management by bispyribac-sodium in transplanted rice. Indian Journal of Weed Science. 45 (3): 151-155.

Li, Y. M., X. H. Du, Q. Zhou and Chen, S. D. 2014. A novel procedure for the synthesis of ammonium glufosinate. Organic Preparations and Procedures International. 46 (6): 565-568.

Maitri D., G. D. Patel, N. K. Patel, S. T. Bhatt and Patel, M. 2017. Effect of different herbicides on Cyperus rotundus L. in turf. Journal of Pharmacognosy and Phytochemistry. 6 (6): 643-647.

Manhas, S. S., G. Singh, D. Singh and Khajuria, V. 2012. Effect of tank-mixed herbicides on weeds and transplanted rice (Oryza sativa L.). Annals of Agriculture Research. 33: 25-31.

Manisankar, G., 2019b. Evaluation of sequential herbicide application in transplanted rice under sodic soil. M.Sc. (Ag.) Thesis, Department of Agronomy, Anbil Dharmalingam Agriculture College and Research Institute, Tamil Nadu agricultural university, Trichy-620 027.

Manisankar, G., T. Ramesh, S. Rathika, P. Janaki and Balasubramanian, P. 2019. Evaluation of sequential herbicide application on transplanted rice under sodic soil. The Pharma Innovation Journal. 8(5): 633-638.

Moody, K., 1977. Weed control in multiple cropping. Cropping Systems Research and Development for the Asian Rice Farmer. pp.281-293.

Mueller, T. C., P. D. Mitchell, B. G.Young and Culpepper, A. S. 2005. Proactive versus reactive management of glyphosateresistant or-tolerant weeds. Weed Technology. 19 (4): 924-933.

Nagaraju, N., B. V. Rao, M. T. Naidu and
Srinivasa Rao, D. 2014. Weed flora and diversity of rice agro ecosystems in Visakhapatnam district of Andhra Pradesh, India. International Journal of Current Research. 6(8): 8018-8022.

Nivetha, C., G. Srinivasan and Shanmugam, P. M. 2017. Effect of Weed Management Practices on Growth and Economics of Transplanted Rice under Sodic Soil. Int.J.Curr.Microbiol.App.Sci. 6 (12): 1909-1915.

Parthipan, T., and Ravi, V. 2016. Productivity of transplanted rice as influenced by weed control methods. Afri. J. Agri. Res 11 (6): 1445-1449.

Parthipan, T., and Ravi, V. 2014. Productivity of transplanted rice as influenced by weed control methods. African Journal of Agricultural Research. 9 (29): 2250-2254.

Parthipan, T., V. Ravi, E. Subramanian and Ramesh, T. 2013. Integrated weed management on growth and yield of transplanted rice and its Residual Effect on Succeeding Black gram. Journal of Agronomy. 12 (2): 99-103.

Patra, A. K., J. Halder and Mishra, M. M. 2011. Chemical weed control in transplanted rice in Hirakud command area of Orissa. Indian Journal of Weed Science. 43 (3\&4): 175-177.

Pline, A. W., J. Wu and Hatzios, K. K. 1999. Absorption, translocation, and metabolism of glufosinate in five weed species as influenced by ammonium sulfate and pelargonic acid. Weed Science. pp. 636-643.

Prakash, C., R. K. Shivran and Koli, N. R. 2013. Bioefficacy of new herbicides in transplanted rice. Indian Journal of Weed Science. 45 (4): 282-284.

Ramachandra, C., N. Shivakumar and Ningaraju, G. K. 2014. Effect of herbicides and their combination on weed dynamics in ricebased cropping system. Indian Journal of Weed Science. 46 (2): 123-125.

Rathika, S., C. Chinnusamy and Ramesh, T. 2013. Efficiency of Halosulfuron Methyl (NC319 75\% WDG) on Weed Control in Sugarcane. International Journal of Agriculture, Environment and Biotechnology. 6 (4): 611. 
Revathi, M., K. Annadurai and Chinnusamy, C. 2017. Effect of various pre and post emergence herbicides on crop yield and weed dynamics under different rice establishment methods in Sodic soil environment. International Journal of Chemical Studies. 5 (5): 1531-1536.

Saha, S., 2006. Comparative study on efficacy of sulfonylurea herbicides and traditional recommended herbicides in transplanted rice (Oryza sativa). Indian Journal of Agronomy. 51 (4): 304-306.

Saini, M. K., and Chopra, S. 2015. Influence of weed control methods on weeds, yield, energetics and economics of basmati rice (Oryza sativa) under sub-mountaineous conditions of Punjab. Indian Journal of Agronomy. 60 (3): 410-413.

Senseman., and Scott, A. 2007. Herbicide handbook: Lawrence, US Weed Science Society of America. pp. 632-954.

Singh, P. V., G. Singh and Singh, M. 2005. Effect of Bensulfuron-methyl (Londax $60 \mathrm{DF}$ ) on sedges and non-grassy weeds in transplanted rice. Indian Journal of Weed Science. 37 (1\&2): 40-44.

Soe Thura., 2010. Evaluation of Weed Management practices in the System of Rice Intensification (SRI). M.Sc. (Ag.) Thesis, Department of Agronomy, Yezin Agricultural University, Yezin, Nay Pyi Taw.

Sreeramalu, K. R., and Prabhakar Shetty, T. K. 1996. Effect of herbicides on microflora of sorghum rhizosphere. Karnataka $J$. Agric. Sci. pp. 559-561.

Subbaiah, S. V., and Sreedevi, B. 2000. Efficacy of Herbicide Mixtures on Weed Control in Direct Seeded Rice under Puddled Condition. Indian Journal of Weed Science. 32 (3\&4): 199-200.

Subramanian, E., S. N. M. Ramachandra Boopathi and Balasubramanian, R. 2004. Relative efficacy of different weed control methods in drum seeded wet rice under puddle conditions. Oryza. 22 (1): 15-19.

Suganthi, M., 2013. Bioefficacy Evaluation of Halosulfuron Methyl, Chlorimuron Ethyl and their Combination for Weed Management in Sugarcane and its Residual Effect on succeeding crops. M.Sc. (Ag.) Thesis, Department of Agronomy, Tamil Nadu Agricultural University, Coimbatore - 641003.

Veeraputhiran, R., and Balasubramanian, R. 2010. Evaluation of new post emergence herbicide in transplanted rice. Proc. National Conference on Challenges in Weed Management in Agro ecosystem: Present Status and Future Strategies. Coimbatore, India. 30 (175).

Veeraputhiran, R., and Balasubramanian, R. 2013. Evaluation of bispyribac-sodium in transplanted rice. Indian Journal of Weed Science. 45 (1): 12-15.

Yadav, D. B., Ashok Yadav and Punia, S. S. 2009. Evaluation of bispyribac-sodium for weed control in transplanted rice. Indian Journal of Weed Science. 41 (1\&2): 23-27.

Zhang, Z. P., 1996. Weed management in transplanted rice. FAO Plant Production and Protection. 139: 75-86.

\section{How to cite this article:}

Manisankar, G., T. Ramesh and Rathika, S. 2020. Weed Management in Transplanted Rice through Pre Plant Application of Herbicides: A Review. Int.J.Curr.Microbiol.App.Sci. 9(05): 684-692. doi: https://doi.org/10.20546/ijcmas.2020.905.076 